\title{
Prognostic Value of Combined Programmed Cell Death I Ligand and pl6 Expression Predicting Responsiveness to Radiotherapy in Patients with Oropharyngeal Squamous Cell Carcinoma
}

\author{
Minsu Kwon ${ }^{1}$, Dae Hwan Kim², Ki Ju Cho ${ }^{2}$, Youngchul Kim², Jin Pyeong Kim²,

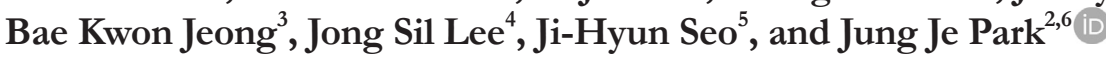 \\ ${ }^{1}$ Department of Otorhinolaryngology, Eulji Medical Center, Eulji University School of Medicine, Seoul; and \\ ${ }^{2}$ Departments of Otorhinolaryngology, ${ }^{3}$ Radiation Oncology, ${ }^{4}$ Pathology, and ${ }^{5}$ Pediatrics, Gyeongsang National University Hospital, \\ Gyeongsang National University School of Medicine, Jinju; and ${ }^{6}$ Institute of Health Sciences, Gyeongsang National University Hospital, \\ Jinju, Korea
}

방사선치료를 받은 구인두 편평상피세포암 환자에서 p16과 Programmed Cell Death 1 Ligand 발현의 예후적 가치

권민수 $^{1} \cdot$ 김대환 ${ }^{2} \cdot$ 조기주 ${ }^{2} \cdot$ 김영철 $^{2} \cdot$ 김진평 $^{2} \cdot$ 정배권 $^{3} \cdot$ 이종실 $^{4} \cdot$ 서지현 $^{5} \cdot$ 박정제 $^{2,6}$

을지대학교 의과대학 을지병원 이비인후과학교실, ${ }^{1}$ 경상대학교 의과대학 경상대학교병원 이비인후과학교실, ${ }^{2}$

방사선종양학교실, ${ }^{3}$ 병리학교실, ${ }^{4}$ 소아과학교실, ${ }^{5}$ 경상대학교 의과대학 건강과학연구원 ${ }^{6}$

Received August 14, 2019

Revised October 2, 2019

Accepted October 28, 2019

Address for correspondence

Jung Je Park, MD, PhD

Department of Otorhinolaryngology,

Gyeongsang National

University Hospital,

Institute of Health Sciences,

Gyeongsang National University

School of Medicine,

79 Gangnam-ro, Jinju 52727, Korea

Tel $+82-55-750-8698$

Fax +82-55-759-0613

E-mail capetown@hanmail.net
Background and Objectives This study examined the expressions of p16 and the programmed cell death 1 ligand (PD-L1) in patients with oropharyngeal cancer (OPC) treated with radiotherapy (RT) to identify the correlation between p16 and PD-L1 expression, and to examine the prognostic significance of these markers for OPC patients receiving RT.

Subjects and Method Forty-eight OPC patients diagnosed and treated at a tertiary referral hospital were enrolled in this retrospective analysis. Patients were initially treated with RT or chemoradiotherapy (CRT) with curative intent and completed the planned schedule. Expression of p16 and PD-L1 by primary tumors was evaluated by immunohistochemistry, and results were interpreted separately and dichotomized according to outcome analyses.

Results Of the 48 patients, $25(52.1 \%)$ expressed p16 and 15 (31.3\%) expressed PD-L1. Expression of these markers showed a mutual positive correlation $(p=0.046)$. Positive PD-L1 expression was associated with poor complete remission (CR) rates after RT $(p=0.040)$. Positive p16 expression was associated with better recurrence-free survival (RFS) $(p=0.004)$ but not overall survival (OS) ( $p=0.192)$. PD-L1 expression showed no independent association with survival $(p>0.05)$; however, PD-L1 expression tended toward poorer RFS, even in p16-positive individuals.

Conclusion There was a positive correlation between the expression of p16 and PD-L1 in OPCs. PD-L1 expression was associated with poorer CR rates after RT or CRT. PD-L1 alone did not show an association with RFS or OS, but when combined with p16, it tended toward poorer RFS, even in p16-positive cases.

Korean J Otorhinolaryngol-Head Neck Surg 2019;62(12):712-9

Key Words Oropharyngeal cancer · Prognosis · Programmed cell death 1 ligand expression · p16 expression · Radiotherapy.

This is an Open Access article distributed under the terms of the Creative Commons Attribution Non-Commercial License (https://creativecommons.org/licenses/by-nc/4.0) which permits unrestricted non-commercial use, distribution, and reproduction in any medium, provided the original work is properly cited. 


\section{Introduction}

The impact of human papilloma virus (HPV) on oropharyngeal cancer (OPC) is currently well-known factor from accumulated numerous studies over recent 2 decades, and HPV-associated OPC shows tendency of occurrence in youngaged non-smokers with relatively aggressive feature, contrarily demonstrating favorable treatment response and survival. ${ }^{1,2)}$ Radiotherapy (RT) alone or with concurrent chemotherapy (CRT) are definitive initial treatment options in OPC, and recent studies have demonstrated that expression of p16, a surrogate marker of HPV, in OPC could predict good responsiveness to RT or CRT. ${ }^{3-5)}$ According to its prognostic significance, American Joint Committee on Cancer (AJCC) released a 8th edition of cancer staging manual on OPC about separated tumor-node-metastasis (TNM) staging based on p16 positivity. ${ }^{6,7)}$

However, there are still OPCs with miserable clinical course regardless of HPV-positivity, especially in locally advanced cases. ${ }^{89)}$ Those can be explained that HPV-positive OPC occasionally demonstrates soft tissue metastasis or extracapsular spread (ECS) in metastatic lymph nodes (LNs), and these may lead to failure of local disease control and low distant metastasis free survival rate. ${ }^{10)}$ On the other hand, there is a contradictory report that ECS is not a negative prognostic factor in HPV-positive OPC, hence there should be careful considerations in planning treatment and forecasting prognosis of OPC patients only with HPV or p16 positivity. ${ }^{11)}$

Based on the concept about responses of host immunity on oncovirus-related carcinogenesis, there were studies reporting importance of composition of immune cells in tumor microenvironment of HPV-positive OPC. ${ }^{12,13)}$ In addition to current hot attention on cancer immunotherapy and its therapeutic targets including programmed cell death 1 ligand (PD-L1), there have been numerous experimental and clinical researches about cancer immunotherapy with noticeable results also in head and neck cancers. ${ }^{14-16)}$ Therefore, there should be considerations not only about HPV status but also about vigorous investigation on immune-associated markers for improving outcomes in the management of patients with OPC in the era of precision medicine.

In this study, we aimed to examine the expressions of p16 and PD-L1 in primary tumor tissues from the patients who had been treated by RT or CRT with curative intent. And we sought to find the correlation between p16 and PD-L1 expressions and finally tried to analyze the prognostic significance of those markers for RT or CRT in OPC patients.

\section{Subjects and Method}

\section{Patients}

We reviewed medical records of the OPC patients who had been diagnosed and treated in our tertiary referral hospital from 2010 to 2017. All patients were initially treated by RT or CRT with curative intent and completed the planned schedule. The inclusion criterion of the study subjects for the analyses were as following: 1) pathologically confirmed squamous cell carcinoma, 2) age at diagnosis $>18$ years old, 3) no evidence of synchronous second primary cancer (SPC), 4) no history of other malignancy within recent 5 years, and 5) followed more than 1 year if survived. The Institutional Review Board approved this study proceeding (IRB No. GNUH 201806-008), and the acquisition of informed consent from the patients was waived due to the retrospective study nature.

\section{Treatment, response evaluation and follow-up}

RT or CRT were performed usually in accordance with National Comprehensive Cancer Network guideline. ${ }^{17)}$ That is, a total dose of 66-70 Gy was irradiated during 6-7 weeks on primary tumor and involved LNs, and in node negative or low to intermediate risk patients received 44-50 Gy on sites of suspected subclinical spread. Intensity modulated RT was used in $32(66.7 \%)$ patients, and 3-dimensional conformal RT was used in 16 (33.3\%) patients, respectively. The concurrent chemotherapy regimen consisted of weekly low dose (40 $\mathrm{mg} / \mathrm{m}^{2}$ ) cisplatin plus conventional fraction to a typical dose of $70 \mathrm{~Gy}$ in 7 weeks, because our center made consensus on such rationale based on the non-inferior treatment outcome compared to high dose cisplatin for improving patients' compliance with low toxicity. ${ }^{18)}$

Patients completed planned RT schedule were evaluated their treatment results on 2-3 months after RT cessation according to the response evaluation criteria in solid tumors 1.1. ${ }^{19)}$ Salvage operation was indicated for patients with residual diseases on primary site or neck after RT or CRT. Patients were followed with meticulous physical and endoscopic examinations, also with scheduled radiologic tests, at every 1-3 months in the first year, every 2-4 months in the second and third year, every 6 months in the fourth and fifth year, and annually thereafter. Any lesions suggestive of recurrences or SPC were confirmed by biopsies or other diagnostic tests. Patients with confirmed recurrence or SPC were scheduled for salvage or palliative treatment, and all surviving patients were followed up for more than 1 year. 


\section{Immunohistochemistry}

A board-certified, experienced pathologist reviewed all pathologic sections and was blinded to clinical data. Paraffinembedded biopsy specimens were obtained from the pathology archives, and tissue microarrays (TMAs) with a core diameter of $2 \mathrm{~mm}$ were constructed from the formalin-fixed blocks. Specific regions (at the invasive front) from the TMA cores of each primary tumor were selected under a microscope and arranged pair-wise in TMA blocks. Each sample was analyzed in duplicate to reduce sampling error and to minimize tissue loss during processing. IHC using antibodies specific for p16 (clone E6H4; CINtec p16 Histology, Ventana Medical Systems, Inc., Oro Valley, AZ, USA) and PD-L1 (clone E1L3N; Cell Signaling Technology, Danvers, MA, USA; 1:200) was performed on $4 \mu \mathrm{m}$ TMA sections using a BenchMark XT automatic immunostaining device (Ventana Medical Systems, Tucson, AZ, USA) and the OptiView DAB IHC Detection Kit (Ventana Medical Systems), in accordance with the manufacturer's instructions. Staining intensity was graded as negative $(=0)$, weak $(=1)$, moderate $(=2)$, or strong $(=3)$, and reactivity was based on the percentage of positively stained cells: $0-5 \%(=0), 5-25 \%(=1), 26-50 \%(=2), 51-75 \%(=3)$, or $76-100 \%(=4)$. The IHC reactivity score (IRS) was calculated
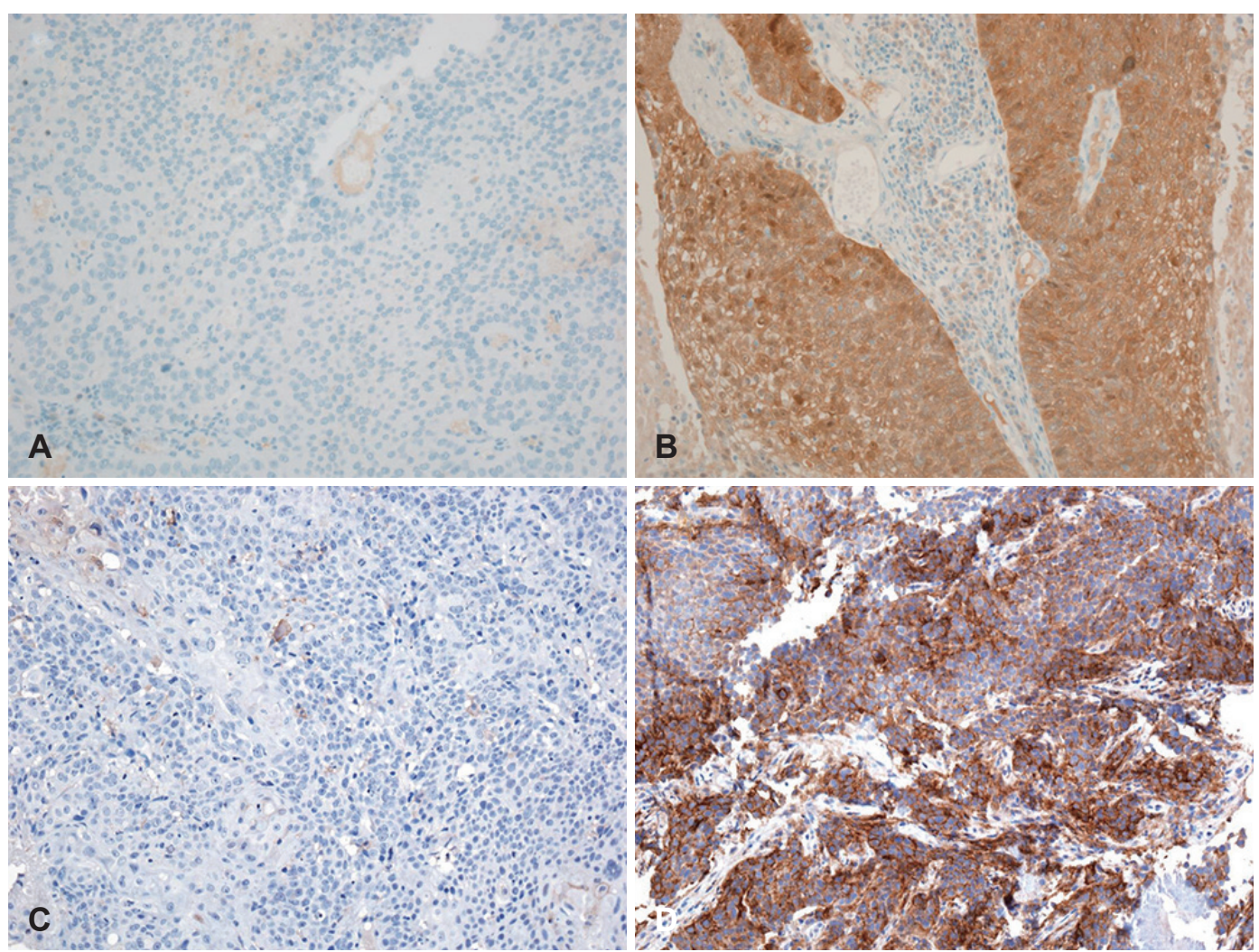

Fig. 1. Representative images in immunohistochemistry. Negative (A) and positive (B) staining on p16. Negative (C) and positive (D) staining on programmed cell death 1 ligand (magnification $\times 200$ ). by multiplying the grade of the staining intensity by that of the staining percentage, giving a minimum score of 0 and a maximum of $12 .{ }^{20)}$ The expression levels of p16 and PD-L1 were interpreted separately and dichotomized to negative (IRS of $0-2$ ) or positive (IRS $\geq 3$ ) groups for outcome analyses. Representative staining results are shown in Fig. 1.

\section{Variables}

The data obtained from the medical records of the patients included age, gender, smoking history, performance status defined by Eastern Cooperative Oncology Group Performance Score, and body-mass index (BMI). Smoking history was dichotomized from 10 pack-years based on the landmark article about OPC prognosis. ${ }^{3)}$ Subsites of the primary tumors were recorded, and TNM stages were defined according to the cancer staging manual from AJCC 8th edition. ${ }^{21)}$ And maximum standardized uptake value (SUVmax) of primary tumor on positron emission tomography (PET)-CT were evaluated.

\section{Statistical analyses}

Correlations between expressions of p16 and PD-L1 and other clinical factors were evaluated using Fisher's exact test or Mann-Whitney U test for categorical or continuous vari- 
ables, respectively. Survival analyses according to p16 and PDL1 expressions were also performed. Kaplan-Meier survival plots were depicted for estimating overall and recurrence-free survivals with comparing parameters via the log-rank test. Cox proportional hazard regression analyses were performed using variables with $p<0.05$ in univariate analyses to elucidate risk factors affecting patients' survival. All statistical analyses were performed using IBM SPSS software version 22.0 (IBM Corp., Armonk, NY, USA), and a two-sided $p<0.05$ denoted statistical significance.

\section{Results}

\section{Patient and tumor characteristics}

A total number of 48 patients met the inclusion criteria. All patients were men with median age of 62 years (ranged 42-86 years) at diagnosis. Palatine tonsil was the most common site of tumor $(60.4 \%)$, and more than half of the patients demonstrated initially cervical nodal metastasis $(68.8 \%)$ and consequently advanced overall stage (72.9\%). Forty (83.3\%) patients received CRT for initial definitive treatment, and other 8 (16.7\%) patients underwent RT only. After completion of treatment, 35 (72.9\%) patients were confirmed as complete remission (CR), $5(10.4 \%)$ patients as partial remission, and $8(16.7 \%)$ patients as progressive disease, respectively. Among the 13 patients with non-CR status, 4 patients received subsequent salvage operations on residual tumor, but other 9 patients did not proceed any further treatment due to their poor general condition or refusal to adjuvant therapy. Median duration of follow-up was 36.8 months (ranged 3.5-111.1 months), and 19 (39.6\%) patients experienced recurrence of tumor and 13 (27.1\%) patients dead during the follow-up period. Above findings were summarized on Table 1.

\section{Correlations of pl6 and PD-LI expression with clinical parameters}

IHC on p16 and PD-L1 from primary tumor tissue were evaluated according to the previously described IRS criteria. Positive stains were identified in $25(52.1 \%)$ cases on p16 and 15 (31.3\%) cases on PD-L1, respectively. Expression of those markers demonstrated a mutual positive correlation $(p=0.046)$. Positive PD-L1 was associated with higher mean SUVmax (10.2 \pm 4.5 vs. $13.8 \pm 6.8, p=0.046)$ on primary tumor and poorer CR rate $(81.8 \%$ vs. $53.3 \%, p=0.040)$ after RT. However, p16 expression did not show neither impact on treatment response nor any correlation with characteristics of patients or tumor
Table 1. Characteristics of the patients $(n=48)$

\begin{tabular}{|c|c|}
\hline & $n(\%)$ \\
\hline $\begin{array}{l}\text { Age at diagnosis, years } \\
\text { [median (range)] }\end{array}$ & $62(42-86)$ \\
\hline $\begin{array}{l}\text { Smoking, }<10 / \geq 10 \\
\text { pack-years }\end{array}$ & $21(43.8) / 27(56.3)$ \\
\hline $\mathrm{BMl},<23 / \geq 23 \mathrm{~kg} / \mathrm{m}^{2}$ & $23(47.9) / 25(52.1)$ \\
\hline ECOG PS, 0/1/2 & $20(41.7) / 23(46.9) / 5(10.2)$ \\
\hline \multicolumn{2}{|l|}{ Tumor characteristics } \\
\hline Site, tonsil/BOT/SP/PPW & $29(60.4) / 9(18.8) / 6(12.5) / 4(8.3)$ \\
\hline T stage, $\mathrm{T} 1-2 / \mathrm{T} 3-4^{*}$ & $32(66.7) / 16(33.3)$ \\
\hline $\mathrm{N}$ stage, $\mathrm{NO} / \mathrm{Nl}-3^{*}$ & $15(31.3) / 33$ (68.8) \\
\hline Overall stage, $|-||/|||-\mid V^{*}$ & $13(27.1) / 35(72.9)$ \\
\hline pl6, negative/positive & $23(47.9) / 25(52.1)$ \\
\hline PD-L1, negative/positive & $33(68.8) / 15(31.3)$ \\
\hline $\begin{array}{l}\text { SUVmax } \\
\text { [median (range)] }\end{array}$ & $11.5(4.2-26.2)$ \\
\hline \multicolumn{2}{|l|}{ Treatment } \\
\hline RT only/CRT & $8(16.7) / 40(83.3)$ \\
\hline $\begin{array}{l}\text { Initial response, } \\
\text { CR/PR/SD/PD }\end{array}$ & $35(72.9) / 5(10.4) / 0(0) / 8(16.7)$ \\
\hline \multicolumn{2}{|l|}{ Follow-up information } \\
\hline $\begin{array}{l}\text { Follow-up duration, } \\
\text { months [median (range)] }\end{array}$ & $36.8(3.5-111.1)$ \\
\hline Recurrences, LRF/DM ${ }^{\dagger}$ & $19(39.6) / 3(6.3)$ \\
\hline $\begin{array}{l}\text { Last status, } \\
\text { NED/AWD/DOD/DOC }\end{array}$ & $30(62.5) / 6(12.5) / 11(22.9) / 2(4.2)$ \\
\hline
\end{tabular}

*staging based on the 8th edition of American Joint Committee on Cancer staging system, tall DM cases coexisted with LRF. AWD: alive with disease, BMI: body-mass index, ВOT: base of tongue, CR: complete remission, CRT: chemoradiotherapy, DM: distant metastasis, DOC: death of other cause, DOD: death of disease, ECOG PS: Eastern Cooperative Oncology Group Performance Score, LRF: locoregional failure, NED: no evidence of disease, PD: progressive disease, PD-L1: programmed cell death 1 ligand, PPW: posterior pharyngeal wall, PR: partial remission, RT: radiotherapy, SD: stable disease, SP: soft palate, SUVmax: maximum standardized uptake value

(all $p>0.05$, Table 2).

\section{Survival analyses according to expression of pl6 and PD-LI}

Table 3 demonstrated factors affecting recurrence-free survival (RFS) and overall survival (OS) of the patients. Smoking history $\geq 10$ pack-years was associated with poorer RFS [hazard ratio (HR) 3.041, 95\% confidence interval (CI) 1.086$8.511, p=0.034]$. Other clinical factors including age, BMI, TNM stage, SUVmax had no significant impact on both RFS and OS. Positivity on p16 showed better RFS (HR 0.249, 95\% CI $0.089-0.695, p=0.008)$ but didn't display a statistical significance on OS (HR 0.481, 95\% CI 0.156-1.479, $p=0.202$ ). However, PD-L1 expression did not demonstrate any association with RFS or OS. 
Table 2. Correlations of $\mathrm{p} 16$ and PD-L1 expression with clinical parameters

\begin{tabular}{|c|c|c|c|c|c|c|}
\hline & $\begin{array}{l}\text { pl6 (-) } \\
(\mathrm{n}=23)\end{array}$ & $\begin{array}{c}\text { Pl6 (+) } \\
(n=25)\end{array}$ & p-value & $\begin{array}{c}\text { PD-L1 (-) } \\
(\mathrm{n}=33)\end{array}$ & $\begin{array}{c}\text { PD-Ll (+) } \\
(n=15)\end{array}$ & p-value \\
\hline Age, $\geq 65$ years & $10(43.5)$ & $8(32.0)$ & 0.552 & $12(36.4)$ & $6(40.0)$ & 0.528 \\
\hline Smoking, $\geq 10$ pack-years & $16(69.6)$ & $11(44.0)$ & 0.089 & $20(60.6)$ & $7(46.7)$ & 0.277 \\
\hline $\mathrm{BMI}, \geq 23 \mathrm{~kg} / \mathrm{m}^{2}$ & $9(39.1)$ & $16(64.0)$ & 0.148 & $17(51.5)$ & $8(53.3)$ & 0.578 \\
\hline \multicolumn{7}{|l|}{ Tumor characteristics } \\
\hline T stage, $\mathrm{T} 3-4^{\dagger}$ & $10(43.5)$ & $6(24.0)$ & 0.222 & $10(30.3)$ & $6(40.0)$ & 0.366 \\
\hline $\mathrm{N}$ stage, $\mathrm{Nl}-3^{+}$ & $14(60.9)$ & $19(76.0)$ & 0.353 & $24(72.7)$ & $9(60.0)$ & 0.289 \\
\hline Overall stage, III-IV† & $16(69.6)$ & $19(76.0)$ & 0.748 & $22(66.7)$ & $13(86.7)$ & 0.136 \\
\hline pl6, positive & NA & NA & NA & $14(42.4)$ & $11(73.3)$ & $0.046^{*}$ \\
\hline PD-L1, positive & $4(17.4)$ & $11(44.0)$ & $0.046^{*}$ & NA & NA & NA \\
\hline SUVmax $($ mean $\pm S D)$ & $12.0 \pm 5.6$ & $10.5 \pm 5.3$ & 0.344 & $10.2 \pm 4.5$ & $13.8 \pm 6.8$ & $0.046^{*}$ \\
\hline Initial treatment response, CR & $15(65.2)$ & $20(80.0)$ & 0.205 & 27 (81.8) & 8 (53.3) & $0.040 *$ \\
\hline
\end{tabular}

Data expressed as number of patients (percent). *characters indicate $p$-value $<0.05$, tstaging based on the 8 th edition of American Joint Committee on Cancer staging system. BMI: body-mass index, CR: complete remission, NA: not available, PD-L1: programmed cell death 1 ligand, SD: standard deviation, SUVmax: maximum standardized uptake value

Table 3. Factors affecting recurrence-free and overall survivals of the patients

\begin{tabular}{|c|c|c|c|c|c|c|}
\hline & \multicolumn{3}{|c|}{ Recurrence-free survival } & \multicolumn{3}{|c|}{ Overall survival } \\
\hline & $\mathrm{HR}$ & $95 \% \mathrm{Cl}$ & p-value & $\mathrm{HR}$ & $95 \% \mathrm{Cl}$ & $p$-value \\
\hline Age, $\geq 65$ years & 1.355 & $0.543-3.380$ & 0.515 & 1.726 & $0.576-5.173$ & 0.330 \\
\hline Smoking, $\geq 10$ pack-years & 3.041 & $1.086-8.511$ & $0.034^{*}$ & 2.232 & $0.685-7.270$ & 0.183 \\
\hline $\mathrm{BMl}, \geq 23 \mathrm{~kg} / \mathrm{m}^{2}$ & 0.710 & $0.288-1.751$ & 0.457 & 0.671 & $0.224-2.010$ & 0.476 \\
\hline \multicolumn{7}{|l|}{ Tumor characteristics } \\
\hline T stage, $\mathrm{T}^{-}-4^{\dagger}$ & 1.355 & $0.533-3.448$ & 0.523 & 1.535 & $0.500-4.712$ & 0.454 \\
\hline $\mathrm{N}$ stage, $\mathrm{Nl}-3^{+}$ & 1.405 & $0.505-3.904$ & 0.515 & 1.668 & $0.458-6.072$ & 0.437 \\
\hline Overall stage, $I I I-I V^{\dagger}$ & 1.617 & $0.535-4.888$ & 0.395 & 2.339 & $0.517-10.592$ & 0.270 \\
\hline pl6, positive & 0.249 & $0.089-0.695$ & $0.008^{*}$ & 0.481 & $0.156-1.479$ & 0.202 \\
\hline PD-L1, positive & 0.906 & $0.326-2.520$ & 0.851 & 1.586 & $0.518-4.859$ & 0.419 \\
\hline SUVmax, $\geq 10$ & 1.321 & $0.529-3.297$ & 0.551 & 1.566 & $0.510-4.809$ & 0.433 \\
\hline
\end{tabular}

*characters indicate $p$-value $<0.05$, tstaging based on the 8th edition of American Joint Committee on Cancer staging system. BMl: body-mass index, Cl: confidence interval, HR: hazard ratio, PD-L1: programmed cell death 1 ligand, SUVmax: maximum standardized uptake value

Because there was no significant impact of p16 and PD-L1 expressions as an independent prognosticator on OS, we additionally analyzed patients' survivals according to the combination of p16 and PD-L1 positivity. Kaplan-Meier survival plots about RFS demonstrated better prognosis of p16 positive group even in combination with PD-L1 positivity. And positive PD-L1 lead to a tendency of poorer RFS even in p16 positive group ( $p=0.030$, Fig. 2 ). On the contrary, neither p16, PD-L1 nor their combination demonstrated any statistically significant impact on OS (all $p>0.05$, Fig. 3).

\section{Discussion}

Mechanism of HPV infection to OPC development have been explained that the viral oncoproteins E6 and E7 downregulate tumor suppressor genes each $\mathrm{p} 53$ and $\mathrm{pRb}$ with in- creasing the p16 expression. ${ }^{22}$ Most of local HPV infection on oropharyngeal mucosa can be cleared through an arrangement of specific $\mathrm{T}$ cell mediated host immune system, however, HPV-positive OPCs also express viral antigens which have immunogenic potential, but cancer occurs by escape from immune surveillance in those patients. That is, tumor persistence may be facilitated by abnormalities in antigen processing, a skewed helper $\mathrm{T}$ cell response, and an increased local prevalence of regulatory T cells in HPV-induced carcinogenesis. ${ }^{23)}$ PD-1 and PD-L1 could be key molecules in such immune escape mechanism on HPV-positive OPCs, and our study demonstrated the positive correlation between p16 and PD-L1 expressions on primary tumor. This result is consistent with a recent study from Australia, but another study on Korean population demonstrated no significant relationship between those markers. ${ }^{24,25)}$ Above 

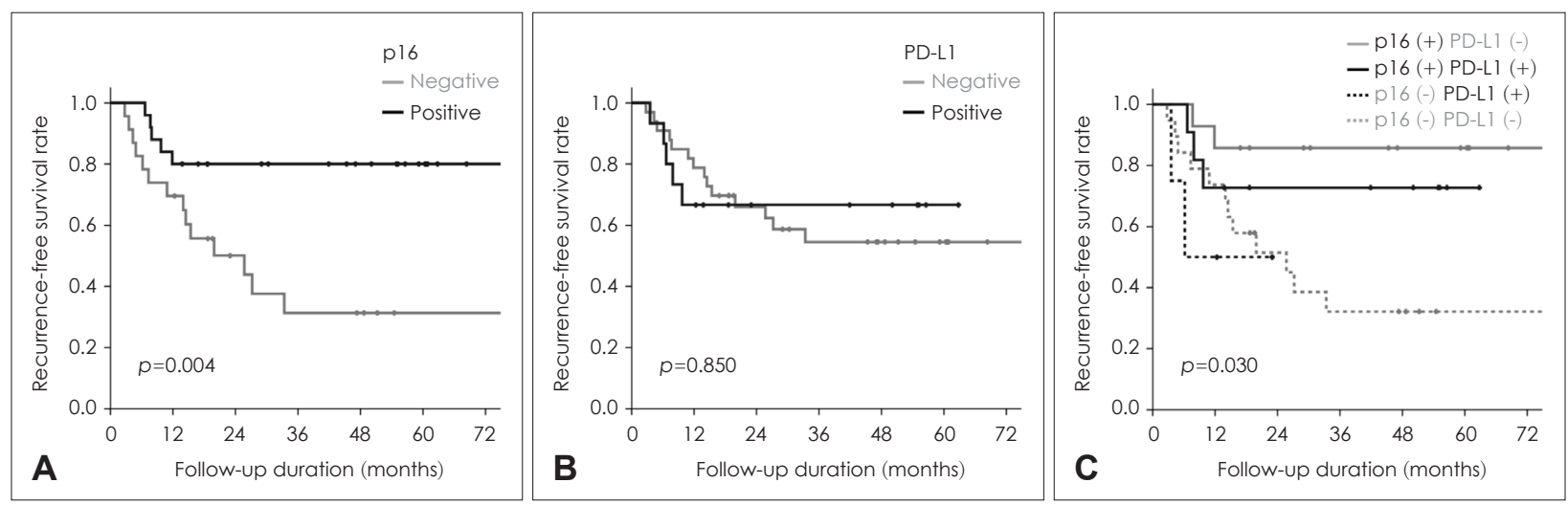

Fig. 2. Recurrence-free survivals according to the expression of p16 (A), PD-L1 (B), and their combination (C). PD-L1: programmed cell death 1 ligand.
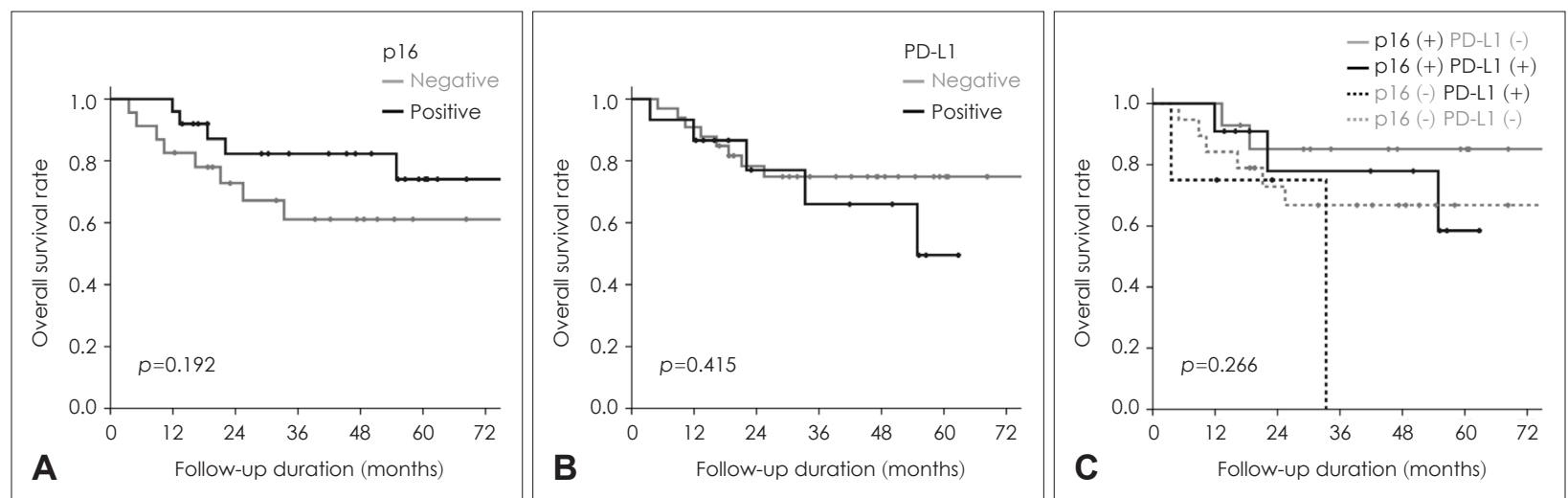

Fig. 3. Overall survivals according to the expression of p16 (A), PD-L1 (B), and their combination (C). PD-L1: programmed cell death 1 ligand.

discrepancy would be derived from diverse cut-off values for determining positive expressions.

The prognosis and response to RT according to PD-L1 expression have not been studied extensively. In studies about colorectal and esophageal cancers, higher expressions of PDL1 were more frequently found in advanced stages, and lower responses to RT with poorer survivals were observed in accordance with high PD-L1 expressions. ${ }^{26-28)}$ However, those studies evaluated CRT outcomes only in the neoadjuvant setting, hence, there would be limitation in terms of estimating prognosis to definitive RT. Another study on nasopharyngeal cancer demonstrated that co-expression of PD-1 and PD-L1 was correlated with poor RFS, however, it reported a 95\% positive rate of PD-L1 using H-score, which would be interpreted as showing somewhat inept IHC finding compared to previous studies. ${ }^{29)}$ A recent study on OPC demonstrated that positive expression of PD-L1 was associated with lower locoregional failure rate (HR 0.57, 95\% CI 0.081-1.07) and death from any cause rate (HR 0.7, 95\% CI 0.46-1.07), but with marginal statistical significance, respectively. ${ }^{30)}$ This study also evaluated the prognostic value of combined expression of p16 and PD-L1, and consequently reported that positive expressions in those 2 markers showed significantly higher survival rates in patients with OPC. In our study, positive PD-L1 was associated with low CR rate after definitive RT/CRT but did not significantly affect RFS or OS. Furthermore, PD-L1 expression was irrelevant to tumor stages and other patients' factors such as age and smoking history. Above negative findings would be derived from evaluating PD-L1 only in primary tumor tissue due to restricted treatment as RT, and further investigation on involved cervical LN which would have more prognostic significances could give additional information about PD-L1 in OPC.

The criteria for defining positivity in IHC results are always controversial. In previous studies, stained range more than $1 \%$ in high power field on microscopy was usually regarded as a positive PD-L1 expression. ${ }^{14,30)}$ However, no worldwide consensus value for the PD-L1 expression is currently present, and there have been reports with diverse criteria of PD-L1 positivity ranged from $5 \%$ to even $20 \%{ }^{25,31)}$ In this study, we used 
IRS for determining the positivity of PD-L1 expression, because we thought that there should be consideration not only about stained range but also about intensity to rule out the false positive results on interpretation of IHC staining. This IRS method would be an arguable point in our study also with the scoring performed by a single pathologist, however, we sought to minimize above errors by repetitive meticulous examination on multiple slides from specimens with blinded clinical information to the head and neck specialized and experienced pathologist.

In our study, p16 expression was significantly associated with RFS but not with OS. Although our results are partially discrepant with known prognostic value of $\mathrm{p} 16$, there was a report that HPV status was not related to survival in patients with advanced head and neck cancers treated by CRT, rather conventional risk factors such as smoking and alcohol consumption were more important prognosticator, and we thought the interpretation of our results could be possible based on such data. ${ }^{8)}$ However, our study demonstrated an inspiring result that positive PD-L1 OPCs were more likely to relapse than negative cases even in p16-positive cases. Although there was low statistical backup, our findings would give a reason to reconsider the recent insistence that de-escalation RT should be performed in p16-positive OPC patients, and we would carefully suggest that the anti-PD-L1 therapeutics may give benefit as a systemic therapy with RT. ${ }^{32}$

Our study did not yield decisive results about the prognostic value of PD-L1 and p16, and it may be caused by retrospectively analyzed data from patients with mixed treatments on various TNM stages. Distant metastasis was found in only 3 patients in this study, and we didn't compare the risk factors including p16 and PD-L1 for distant metastasis after curative RT which is a highlighted problem in CRT received OPC patients, this would be mainly due to the relatively small number of patients with short observation period. In addition, we tried to investigate the impact of PD-L1 expression with other multifactorial prognostic factors including smoking and ECS status, but failed to get meaningful results mainly because of the small sample size with consequently impossible multivariate analyses. Further considerations would be necessary about overcoming the limitation of IHC reading with co-evaluation of immunogenic marker in involved LNs to confirm the results of our study.

In conclusion, expression of p16 in primary OPC tissues correlated positively with that of PD-L1 in our study. PD-L1 positivity was associated with poorer $\mathrm{CR}$ rates after RT or
CRT. Positive p16 expression was associated with better RFS but not OS. PD-L1 expression alone did not demonstrate an association with RFS or OS, but combined expression of p16 and PD-L1 tended toward a poorer RFS, even in the p16-positive group. Further well-designed and large scale studies are needed to further examine the prognostic value of p16 and $\mathrm{PD}-\mathrm{L} 1$ expression in OPC patients receiving RT.

\section{Acknowledgments}

The biopsy specimens and data used in this study were provided by the Biobank of Gyeongsang National University Hospital, a member of Korea Biobank Network.

This work is supported by the National Research Foundation of Korea (NRF) grant funded by the Ministry of Education (NRF-2017 R1D1A3B03033729 and NRF-2017A2B4010122).

\section{ORCID}

Jung Je Park

https://orcid.org/0000-0001-6325-0398

\section{REFERENCES}

1) Ang KK, Sturgis EM. Human papillomavirus as a marker of the natural history and response to therapy of head and neck squamous cell carcinoma. Semin Radiat Oncol 2012;22(2):128-42.

2) Sano D, Oridate N. The molecular mechanism of human papillomavirus-induced carcinogenesis in head and neck squamous cell carcinoma. Int J Clin Oncol 2016;21(5):819-26.

3) Ang KK, Harris J, Wheeler R, Weber R, Rosenthal DI, NguyenTân PF, et al. Human papillomavirus and survival of patients with oropharyngeal cancer. N Engl J Med 2010;363(1):24-35.

4) Lassen P, Primdahl H, Johansen J, Kristensen CA, Andersen E, Andersen LJ, et al. Impact of HPV-associated p16-expression on radiotherapy outcome in advanced oropharynx and non-oropharynx cancer. Radiother Oncol 2014;113(3):310-6.

5) Galloway TJ, Zhang QE, Nguyen-Tan PF, Rosenthal DI, Soulieres D, Fortin A, et al. Prognostic value of p16 status on the development of a complete response in involved oropharynx cancer neck nodes after cisplatin-based chemoradiation: A secondary analysis of NRG oncology RTOG 0129. Int J Radiat Oncol Biol Phys 2016;96(2):362-71.

6) Huang SH, Xu W, Waldron J, Siu L, Shen X, Tong L, et al. Refining American Joint Committee on Cancer/Union for International Cancer Control TNM stage and prognostic groups for human papillomavirus-related oropharyngeal carcinomas. J Clin Oncol 2015;33(8):836-45.

7) Lydiatt WM, Patel SG, O’Sullivan B, Brandwein MS, Ridge JA, Migliacci JC, et al. Head and neck cancers-major changes in the American Joint Committee on cancer eighth edition cancer staging manual. CA Cancer J Clin 2017;67(2):122-37.

8) Descamps G, Karaca Y, Lechien JR, Kindt N, Decaestecker C, Remmelink M, et al. Classical risk factors, but not HPV status, predict survival after chemoradiotherapy in advanced head and neck cancer patients. J Cancer Res Clin Oncol 2016;142(10):2185-96.

9) Samuels SE, Eisbruch A, Beitler JJ, Corry J, Bradford CR, Saba NF, et al. Management of locally advanced HPV-related oropharyngeal squamous cell carcinoma: Where are we? Eur Arch Otorhinolaryngol 2016;273(10):2877-94.

10) Sinha P, Lewis JS Jr, Kallogjeri D, Nussenbaum B, Haughey BH. Soft tissue metastasis in p16-positive oropharynx carcinoma: Prevalence and association with distant metastasis. Oral Oncol 2015;51(8):778-86.

11) Mermod M, Tolstonog G, Simon C, Monnier Y. Extracapsular 
spread in head and neck squamous cell carcinoma: A systematic review and meta-analysis. Oral Oncol 2016;62:60-71.

12) Lee YS, Park JY, Cho KJ, Kim SB, Lee SW, Choi SH, et al. Composition of inflammatory cells regulating the response to concurrent chemoradiation therapy for HPV $(+)$ tonsil cancer. Oral Oncol 2015;51(12):1113-9.

13) Oguejiofor K, Hall J, Slater C, Betts G, Hall G, Slevin N, et al. Stromal infiltration of CD8 $\mathrm{T}$ cells is associated with improved clinical outcome in HPV-positive oropharyngeal squamous carcinoma. Br J Cancer 2015;113(6):886-93.

14) Ferris RL, Blumenschein G Jr, Fayette J, Guigay J, Colevas AD, Licitra L, et al. Nivolumab for recurrent squamous-cell carcinoma of the head and neck. N Engl J Med 2016;375(19):1856-67.

15) De Meulenaere A, Vermassen T, Aspeslagh S, Huvenne W, Van Dorpe J, Ferdinande L, et al. Turning the tide: Clinical utility of PDL1 expression in squamous cell carcinoma of the head and neck. Oral Oncol 2017;70:34-42.

16) De Meulenaere A, Vermassen T, Aspeslagh S, Deron P, Duprez F, Laukens D, et al. Tumor PD-L1 status and CD8+ tumor-infiltrating T cells: Markers of improved prognosis in oropharyngeal cancer. Oncotarget 2017;8(46):80443-52.

17) Network NCC. NCCN Clinical Practice Guidelines in oncology: Head and neck cancers. version 2. [cited 2018 Jul 20]. Available from: URL: https://www.nccn.org/default.aspx.

18) Kang MH, Kang JH, Song HN, Jeong BK, Chai GY, Kang K, et al. Concurrent chemoradiation with low-dose weekly cisplatin in locally advanced stage IV head and neck squamous cell carcinoma. Cancer Res Treat 2015;47(3):441-7.

19) Eisenhauer EA, Therasse P, Bogaerts J, Schwartz LH, Sargent D, Ford R, et al. New response evaluation criteria in solid tumours: Revised RECIST guideline (version 1.1). Eur J Cancer 2009;45(2): 228-47.

20) Kwon M, Kim JW, Roh JL, Park Y, Cho KJ, Choi SH, et al. Recurrence and cancer-specific survival according to the expression of IL-4R $\alpha$ and IL-13R $\alpha 1$ in patients with oral cavity cancer. Eur J Cancer 2015;51(2):177-85.

21) Amin MB, Edge SB, Greene FL, Byrd DR, Compton CC, Fritz AG, et al. AJCC Cancer Staging Manual. 8th ed. New York, NY: Springer;2017.

22) Oguejiofor KK, Hall JS, Mani N, Douglas C, Slevin NJ, Homer J, et al. The prognostic significance of the biomarker p16 in oropharyngeal squamous cell carcinoma. Clin Oncol (R Coll Radiol) 2013;25(11): 630-8.

23) Andersen AS, Koldjaer Sølling AS, Ovesen T, Rusan M. The interplay between HPV and host immunity in head and neck squamous cell carcinoma. Int J Cancer 2014;134(12):2755-63.

24) Hong AM, Vilain RE, Romanes S, Yang J, Smith E, Jones D, et al. PD-L1 expression in tonsillar cancer is associated with human papillomavirus positivity and improved survival: Implications for anti-PD1 clinical trials. Oncotarget 2016;7(47):77010-20.

25) Kim HS, Lee JY, Lim SH, Park K, Sun JM, Ko YH, et al. Association between PD-L1 and HPV status and the prognostic value of PD-L1 in oropharyngeal squamous cell carcinoma. Cancer Res Treat 2016; 48(2):527-36.

26) Saigusa $S$, Toiyama $Y$, Tanaka $K$, Inoue $Y$, Mori $K$, Ide $S$, et al. Implication of programmed cell death ligand 1 expression in tumor recurrence and prognosis in rectal cancer with neoadjuvant chemoradiotherapy. Int J Clin Oncol 2016;21(5):946-52.

27) Lim SH, Hong M, Ahn S, Choi YL, Kim KM, Oh D, et al. Changes in tumour expression of programmed death-ligand 1 after neoadjuvant concurrent chemoradiotherapy in patients with squamous oesophageal cancer. Eur J Cancer 2016;52:1-9.

28) Chen MF, Chen PT, Chen WC, Lu MS, Lin PY, Lee KD. The role of PD-L1 in the radiation response and prognosis for esophageal squamous cell carcinoma related to IL-6 and T-cell immunosuppression. Oncotarget 2016;7(7):7913-24.

29) Zhang J, Fang W, Qin T, Yang Y, Hong S, Liang W, et al. Coexpression of PD-1 and PD-L1 predicts poor outcome in nasopharyngeal carcinoma. Med Oncol 2015;32(3):86.

30) Hong AM, Ferguson P, Dodds T, Jones D, Li M, Yang J, et al. Significant association of PD-L1 expression with human papillomavirus positivity and its prognostic impact in oropharyngeal cancer. Oral Oncol 2019;92:33-9.

31) Sato F, Ono T, Kawahara A, Kawaguchi T, Tanaka H, et al. Prognostic impact of p16 and PD-L1 expression in patients with oropharyngeal squamous cell carcinoma receiving a definitive treatment. J Clin Pathol 2019;72(8):542-9.

32) Masterson L, Moualed D, Liu ZW, Howard JE, Dwivedi RC, Tysome JR, et al. De-escalation treatment protocols for human papillomavirus-associated oropharyngeal squamous cell carcinoma: A systematic review and meta-analysis of current clinical trials. Eur J Cancer 2014;50(15):2636-48. 